\title{
CURRENT BIOCHEMISTRY
}

ISSN: $2355-7877$

Homepage: http://biokimia.ipb.ac.id

E-mail: current.biochemistry@gmail.com

\section{Deodorization of Latex Waste and Decolorization of Textile-Coloring Agent by Omphalina sp. using Batch and Continuous Methods}

(Deodorisasi Limbah Lateks dan Dekolorisasi Zat Pewarna Tekstil dengan Jamur Pelapuk Putih Omphalina sp menggunakan Metode Batch dan Kontinyu)

Erna Puspasari ${ }^{1}$, I Made Artika ${ }^{1}$, Tri Panji ${ }^{2, *}$

${ }^{1}$ Department of Biochemistry, Bogor Agricultural University, Bogor, 16680, Indonesia ${ }^{2}$ Indonesian Research Institute for Biotechnology and Bioindustry, Bogor, 16151, Indonesia

Received :30 July 2015; Accepted: 18 November 2015

Corresponding author: Dr. I Made Artika, M.App.Sc; Departemen Biokimia, Jl. Agatis Gd. Fapet Lt. 5, Wing 5, Bogor 16680; Telp/Fax.+62251-8423267; E-mail: imart@ipb.ac.id

\begin{abstract}
Generally industrial waste water is a pollutant to environment as it produces strong odor and color. Omphalina sp is one of white rot fungi that can be used as an odor and color effluent reducer. Omphalina sp has laccase enzyme that plays role in deodorization and decolorization. The aim of this research was to determine the best method in deodorization and decolorization among batch and continous (pack bed flow, biotray, and rotary contactor) methods. The results of deodorization and decolorization showed that the rotary contactor method was better than the batch, pack bed flow and biotray methods. At dye concentration of 50 ppm, after 24 hours treatment, the absorbance value for batch, pack bed flow, biotray, and rotary contactor methods was 0.520, 0.423, 0.425, and 0.357 , respectively. At dye concentration of $150 \mathrm{ppm}$, after 24 hour treatment, the absorbance value for batch, pack bed flow, biotray, and rotary contactor methods was 0.709, 0.629, 0.658, and 0.592, respectively. At dye concentration of $50 \mathrm{ppm}$, percentage of dye absorption after 24 hour treatment for batch, pack bed flow, biotray, and rotary contactor methods was $20.550 \%, 35.447 \%, 35.141 \%$ and $45.531 \%$ respectively. At dye concentration of $150 \mathrm{ppm}$, percentage of dye absorption after 24 hour treatment for batch, pack bed flow, biotray, and rotary contactor methods was $7.320 \%, 17.843$ $\%, 13.987 \%$, and $22.614 \%$. The qmaks value at dye concentration of 50 ppm after 24 hour treatment for batch, pack bed flow, biotray, and rotary contactor methods was 0.020, 0.076, 0.083, and 0.124 respectively. qmaks value at dye concentration of 150 ppm after 24 hour treatmeny for batch, pack bed flow, biotray, and rotary contactor methods was 0.009, 0.077, 0.046, and 0.100 respectively. Odor scale for batch, pack bed flow, biotray, and rotary contactor methods decreased from 5 to 2.9, $1.4,1.6$ and 1.1 respectively.
\end{abstract}

Keywords: batch, biotray, Omphalina sp, pack bed flow, rotary contactor 


\section{ABSTRAK}

Air limbah industri umumnya merupakan polutan bagi lingkungan karena menghasilkan warna dan bau yang kuat. Omphalina sp adalah salah satu jenis jamur pelapuk putih yang dapat digunakan sebagai penurun warna dan bau pada limbah. Omphalina sp memiliki enzim lakase yang berperan dalam dekolorisasi dan deodorisasi. Tujuan penelitian ini untuk menentukan metode terbaik untuk deodorisasi dan dekolorisasi diantara metode batch dan kontinyu (pack bed flow, biotray dan rotary contactor). Hasil deodorisasi dan dekolorisasi menunjukkan bahwa metode rotary contactor lebih baik dibandingkan metode batch, pack bed flow dan biotray. Nilai absorbansi zat warna 50 ppm setelah 24 jam perlakuan pada metode batch, pack bed flow, biotray, dan rotary contactor berturut-turut adalah 0.520, 0.423, 0.425, dan 0.357. Nilai absorbansi zat warna 150 ppm setelah 24 jam perlakuan pada metode batch, pack bed flow, biotray, dan rotary contactor berturut-turut adalah 0.709, 0.629, 0.658, dan 0.592. Persen penyerapan zat warna pada konsentrasi 50 ppm setelah 24 jam pada metode batch, pack bed flow, biotray, dan rotary contactor berturut-turut adalah $20.550 \%$, $35.447 \%$, 35.141\% dan $45.531 \%$. Persen penyerapan zat warna pada konsentrasi 150 ppm setelah 24 jam pada metode batch, pack bed flow, biotray, dan rotary contactor berturut-turut adalah 7.320 $\%, 17.843 \%, 13.987 \%$, dan $22.614 \%$. Nilai qmaks zat warna konsentrasi 50 ppm setelah 24 jam pada metode batch, pack bed flow, biotray, dan rotary contactor berturut-turut adalah 0.020, 0.076, 0.083, dan 0.124. Nilai qmaks pada zat warna konsentrasi 150 ppm setelah 24 jam pada metode batch, pack bed flow, biotray, dan rotary contactor berturut-turut adalah 0.009, 0.077, 0.046, dan 0.100. Skala bau pada metode batch, pack bed flow, biotray, dan rotary contactor berkurang dari 5 berturut-turutmenjadi 2.9, 1.4, 1.6, dan 1.1.

Kata kunci: batch, biotray, Omphalina sp, pack bed flow, rotary contactor

\section{PENDAHULUAN}

Pertambahan jumlah penduduk yang semakin pesat mengakibatkan bertambahnya kegiatan industri dalam rangka memenuhi kebutuhan manusia. Bertambahnya kegiatan industri mengaibatkan peningkatan limbah. Selain berbahaya, terkadang limbah hasil buangan berwarna dan berbau tajam, sehingga limbah perlu diolah sebelum dilepas ke lingkungan. Limbah warna berasal dari zat warna yang digunakan dalam industri tekstil. Zat warna yang umum digunakan dalam industri tekstil adalah zat warna azo (direct red, remazol black, dan acid orange). Zat warna ini tergolong zat warna sintetik berupa molekul dengan sistem elektron terdelokalisasi dan mengandung gugus kromo- for dan auksokrom. Kromofor menyebabkan terjadinya warna melalui perubahan pita serapan pada daerah tampak (Van de Zee 2002). Menurut Budiawan (2001), bau adalah salah satu parameter pencemaran yang merupakan sumber dari gangguan fisik dan non fisik dimana penyebarannya terjadi melalui udara sebagai medium. Ini membutuhkan penanganan yang serius berupa pengolahan limbah hasil buangan industri. Limbah yang dibuang ke lingkungan harus memenuhi syarat-syarat buangan limbah agar aman bagi lingkungan.

Degradasi anaerobik zat warna oleh bakteri dilaporkan menghasilkan produk karsinogenik dan/atau mutagenik (Stolz 2001). Potensi biodegradasi zat warna oleh jamur, khususnya 
jamur pelapuk putih, lebih baik dibandingkan oleh bakteri karena jamur memiliki kemampuan mendegradasi komponen warna yang bersifat toksik, dan kemampuan transformasi, yaitu merubah bahan kimia berbahaya pada limbah menjadi bahan bahan yang tidak berbahaya (Awaluddin et al. 2001). Selain itu, potensi biodegradasi lignin pada jamur pelapuk putih menjadikan metode biocleaning efisien pada industri pewarna dan limbah yang terkait.

Beberapa penelitian telah dilakukan menggunakan jamur pelapuk putih untuk mendegradasi limbah (Bakshi et al. 1999, Robinson et al. 2001, Wesenberg et al. 2002). Penelitian lain juga menggunakan jamur pelapuk putih Dichomitus squalens, Irpex flavus dan Phlebia spp, Phanerochaete chrysosporium dan Chrysosporium lignorum CL 1 untuk dekolorisasi zat warna (Chander, et al. 2004, Gill, et al. 2002, Awaluddin 2001, Buckley 1998). Penelitian tersebut baru menggunakan beberapa spesies dari keseluruhan jamur pelapuk putih yang ada, sehingga perlu dikembangkan lebih lanjut penggunaan jamur pelapuk putih dari spesies yang berbeda dan limbah hasil industri yang berbeda. Selain itu, perlu dikembangkan lebih lanjut teknik pengolahan limbah dengan jamur pelapuk putih, karena berkaitan dengan efektivitas pengolahan limbah, biaya yang dikeluarkan saat pengolahan limbah, dan keamanan lingkungan. Beberapa metode telah diaplikasikan dalam pengolahan limbah lateks dan zat pewarna tekstil untuk menentukan teknik absorpsi terbaik. Dalam penelitian ini digunakan metode pengolahan limbah yang berupa metode batch dan kontinyu (pack bed flow, biotray dan rotary contactor) menggunakan jamur pelapuk putih Omphalina sp. Jamur ini juga digunakan oleh Ardhina (2007) untuk dekolorisasi limbah menggunakan berbagai macam media. Azizah (2008) juga menggunakan Omphalina sp untuk mencari formula terbaik pada deodorisasi limbah lateks dan dekolorisasi zat pewarna tekstil.

\section{METODOLOGI}

Bahan-bahan yang digunakan dalam penelitian ini adalah Omphalina sp (diperoleh dari Pusat Penelitian Bioteknologi dan Bioindustri Indonesia), kentang, gula pasir, bubuk agar, ijuk, beras pera, serbuk gergaji, pepton, air, aquades steril, alkohol $70 \%$, zat warna merah lombok (Wantex, Padi Gunting, No seri 1) dengan konsentrasi awal 150 ppm dan 50 ppm, limbah lateks.

Alat-alat yang digunakan antara lain neraca analitik, autoklaf, laminar air flow cabinet, vortex, oven, spektrofotometer UV-Vis (UV mini 1240 Shimadzu), neraca kasar, cawan Petri, labu Erlenmeyer, gelas ukur, tabung reaksi, pipet tetes, pipet mikro, alumunium foil, sudip, bunsen, jarum ose, dan alat gelas lain (Pyrex).

\section{Pembuatan PDA (Potatoes Dextrose Agar) (Fassatiova 1986 dalam Ardhina, Aried 2007)}

Kentang sebanyak 200 gram (telah dikupas dan dibersihkan) dimasukkan ke dalam wadah, ditambahkan 1 liter air, kemudian direbus hingga mendidih. Air rebusan kentang disaring dan dimasukkan ke dalam labu Erlenmeyer 1 liter, campur dengan 20 gram gula, lalu dimasukkan ke dalam 2 labu Erlenmeyer masing-masing $500 \mathrm{~mL}$. Sebanyak 10 gram agar ditambahkan pada masing-masing labu Erlenmeyer tersebut, dipanaskan dan diaduk sampai homogen. Sterilisasi dilakukan pada suhu $121^{\circ} \mathrm{C}, 1 \mathrm{~atm}$ selama 15 menit. 
Penyiapan Omphalina sp dalam Media PDA Kultur Omphalina sp dari stok (media PDA dalam cawan Petri) dipotong $1 \mathrm{~cm}^{2}$ untuk diremajakan pada media PDA yang baru, dikulturkan dalam cawan Petri dan dibiarkan tumbuh selama 5-7 hari sampai tumbuh sempurna/merata (Metode Pusat Penelitian Bioteknologi dan Bioindustri Indonesia dengan modifikasi dari Dirmawarnita, et al. 2015).

\section{Penyiapan Kultur Omphalina sp. dalam Me- dia Beras}

Beras sebanyak satu liter dicuci sampai bersih, lalu ditambahkan sedikit air, kemudian dimasak sambil diaduk sampai airnya tidak tersisa, ditambahkan 1 sendok makan minyak agar beras tidak menggumpal. Sebanyak 100 gram beras dimasukkan ke dalam botol dan ditutup botol tersebut. Sterilisasi dilakukan pada suhu $121{ }^{\circ} \mathrm{C}, 1 \mathrm{~atm}$, selama 15 menit. Setengah Petri isolat Omphalina sp dari media PDA dimasukkan ke dalam media beras, diaduk, kemudian diinkubasi pada suhu ruang sampai tumbuh sempurna/ merata selama 7 - 14 hari (Metode Pusat Penelitian Bioteknologi dan Bioindustri Indonesia dengan modifikasi dari Dimawarnita, et al. 2015).

\section{Penyiapan Kultur Omphalina sp. dalam Me- dia Serbuk Gergaji}

Serbuk gergaji yang telah dicuci bersih dimasukkan ke dalam plastik tahan panas (berat serbuk sekitar 500 - 700 gram). Sterilisasi dilakukan pada suhu $121{ }^{\circ} \mathrm{C}, 1 \mathrm{~atm}$, selama 15 menit lalu ditiriskan, dilakukan pengulangan sterilisasi sebanyak dua kali, lalu ditiriskan. Sebanyak 18 gram isolat Omphalina sp dari media beras, diinkubasi sampai tumbuh merata (30 60 hari) (Metode Pusat Penelitian Bioteknologi dan Bioindustri Indonesia dengan modifikasi dari Dirmawarnita, et al. 2015)

\section{Amobilisasi Omphalina sp}

Ijuk dipotong dengan ukuran $5-7 \mathrm{~cm}$, lalu direndam dalam air selama satu minggu, setiap hari dilakukan penggantian air rendaman ijuk untuk menghilangkan kotoran, kemudian ditiriskan hingga kadar air mencapai maksimal $50 \%$. Dilakukan sterilisasi ijuk pada suhu $121{ }^{\circ} \mathrm{C}$ selama 15 menit. Setelah dingin, sebanyak 5 gram ijuk digunakan untuk melapisi formula secara merata (Metode Pusat Penelitian Bioteknologi dan Bioindustri Indonesia dengan modifikasi dari Dirmawarnita, et al. 2015)

\section{Analisis dekolorisasi dengan metode spektro- fotometri}

Analisis dekolorisasi sampel menggunakan spektrofotometer UV-Vis pada zat warna dengan mencari absorbansi maksimal warna tersebut. Analisis dekolorisasi ditinjau berdasarkan tiga hal, penurunan absorbansi zat warna merah lombok, persen penyerapan zat warna merah lombok dan penentuan serapan maksimum $\left(\mathrm{q}_{\text {maks }}\right)$ zat warna merah lombok.

\section{Pengukuran absorbansi zat warna merah lombok}

Penentuan $\lambda_{\text {maks }}$ dengan mencari serapan maksimum pada zat warna merah lombok dilakukan dengan mengukur absorbansi pada beberapa panjang gelombang yang berbeda. Digunakan $\lambda_{\text {maks }}$ yang telah didapat digunakan untuk mengukur absorbansi pada setiap sampel zat warna. 
Persen Penyerapan zat warna merah lombok

Persen penyerapan zat warna merah lombok dihitung dengan menggunakan rumus:

Persen penurunan penyerapan $=[($ Ao-A $) / A o] \times 100 \%$ Ao $=$ absorbansi awal sebelum absorpsi $(\mathrm{nm})$

$\mathrm{A}=$ absorbansi setelah absorpsi $(\mathrm{nm})$

\section{Penentuan Serapan Maksimum $\left(q_{\text {maks }}\right)$ Zat} Warna Merah Lombok

Hasil absorbansi yang didapat dikonversi menjadi konsentrasi (ppm) dengan menggunakan rumus :

$$
\mathrm{A}_{1} / \mathrm{A}_{2}=\mathrm{C}_{1} / \mathrm{C}_{2}
$$

$\mathrm{A}_{1}=$ absorbansi sampel 1

$\mathrm{A}_{2}=$ absorbansi sampel 2

$\mathrm{C}_{1}=$ konsentrasi sampel 1

$\mathrm{C}_{2}=$ konsentrasi sampel 2

Konsentrasi yang didapat berdasarkan perhitungan di atas digunakan untuk menentukan serapan maksimum $\left(\mathrm{q}_{\text {maks }}\right)$ berdasarkan model persamaan isotermsorbsi Langmuir (Suharyanto 2014):

$$
\frac{1}{q}=\frac{1}{b \text { qmax }} \quad \frac{1}{C f}+\frac{1}{q \max }
$$

Keterangan :

$\mathrm{q}=$ konsentrasi adsorbat yang terjadi

(massa adsorbat/ massa biosorben)

qmax $=$ jumlah maksimum zat warna yang dapat diserap biosorben $(\mathrm{mg} / \mathrm{g})$

Cf = konsentrasi akhir zat warna dalam larutan

b $\quad=$ konstanta Langmuir

\section{Analisis deodorisasi dengan uji organoleptik}

Analisis deodorisasi pada sampel limbah lateks pekat dilakukan dengan uji organoleptik, yaitu membaui sampel yang ada kemudian diu- kur dengan skala yang menunjukkan tingkat bau ( 5 = sangat bau; $4=$ lebih bau; $3=$ bau; $2=$ kurang bau; 1 = tidak bau). Sampel tanpa perlakuan sebagai acuan nilai tertinggi (skala 5). Pengujian deodorisasi ini menggunakan panelis sebanyak 7 orang mahasiswa IPB dan mahasiswa Universitas Udayana dengan memberikan skor (nilai) berdasarkan skala yang diberikan.

\section{Penentuan Kemampuan Deodorisasi dan Dekolorisasi}

Metode batch dilakukan dengan cara memasukkan larutan yang berisi zat warna dan limbah lateks ke dalam wadah, kemudian diinokulasi Omphalina sp yang digunakan dengan cara merendamnya ke dalam sampel. Dilakukan pengukuran intensitas warna pada jam ke 1, 3, 5, 7, dan 24. Pengukuran intensitas bau dilakukan pada jam ke 1, 3, 5, 7, 24, 26 dan 28 (Gambar 1a).

Penentuan deodorisasi dan dekolorisasi pada metode pack bed flow dilakukan dengan cara mengalirkan larutan dengan laju alir 0.173 L/s. Bak yang berisi formula Omphalina sp dialiri oleh larutan yang baru secara terus-menerus hingga kemampuan deodorisasi dan dekolorisasinya berkurang, kemudian dilakukan pengukuran intensitas warna dan bau (Gambar 1b).

Penentuan deodorisasi dan dekolorisasi pada metode biotray dilakukan dengan cara memancurkan air limbah dari ketinggian tertentu melewati bak yang berisi formula Omphalina sp dengan laju alir $0.173 \mathrm{~L} / \mathrm{s}$ terus-menerus hingga kemampuan deodorisasi dan dekolorisasinya berkurang, kemudian dilakukan pengukuran intensitas warna dan bau (Gambar 1c).

Penentuan deodorisasi dan dekolorisasi pada metode rotary contactor dilakukan dengan memutar wadah yang berisi formula Omphalina 
sp. Air limbah secara terus menerus dialirkan melewati pipa ke wadah dengan kecepatan 0.173 $\mathrm{L} / \mathrm{s}$, sehingga wadah yang berisi formula $\mathrm{Om}$ phalina sp akan berputar secara terus menerus hingga kemampuan deodorisasi dan dekolorisasinya berkurang, kemudian dilakukan pengukuran intensitas warna dan bau (Gambar 1).

\section{Hasil}

\section{Kemampuan Dekolorisasi}

Pengukuran absorbansi zat warna merah lombok dengan konsentrasi awal 50 ppm dan 150 ppm dilakukan dengan menggunakan spektrofotometri UV-VIS. Hasil pengukuran menunjukkan terjadinya dekolorisasi zat warna merah lombok yang ditunjukkan dengan terjadinya penurunan absorbansi pada setiap metode. Pengenceran dilakukan sebanyak dua kali pada konsentrasi 50 ppm dan 5 kali pengenceran pada konsentrasi 500 ppm pada saat pembacaan absorbansi. Pengenceran ini bertujuan agar hasil dekolorisasi dapat terbaca oleh spektrofotometri UV-VIS.

Absorbansi yang terbaca pada konsentrasi 50 ppm adalah 0.655 , kemudian penurunan absorbansi jam ke-24 pada metode batch menjadi 0.520 , pada metode pack bed flow menjadi 0.423 , pada metode biotray menjadi 0.425 , pada metode rotary contactor menjadi 0.357 (Gambar 2a). Konsentrasi 150 ppm, menghasilkan pembacaan absorbansi 0.765 , kemudian absorbansi menurun pada jam ke-24 pada metode batch

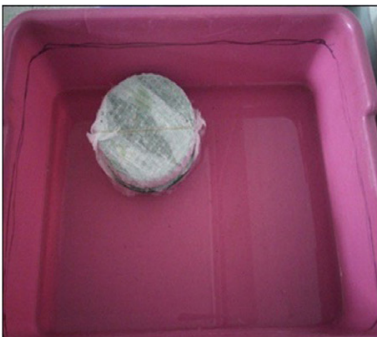

(a)

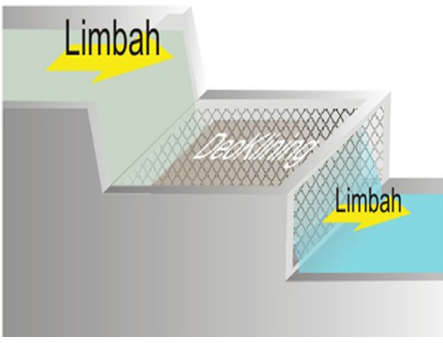

(b)

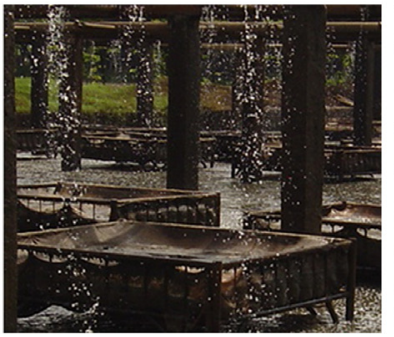

(c)

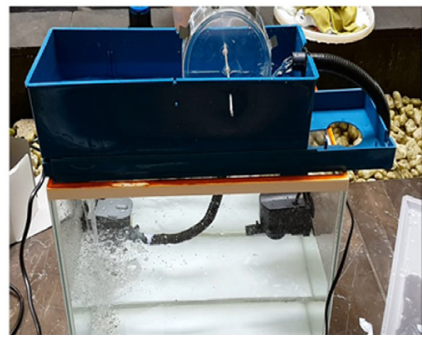

(d)

Gambar 1 Rangkaian metode (a) batch, (b) pack bed flow, (c) biotray, (d) rotary contactor
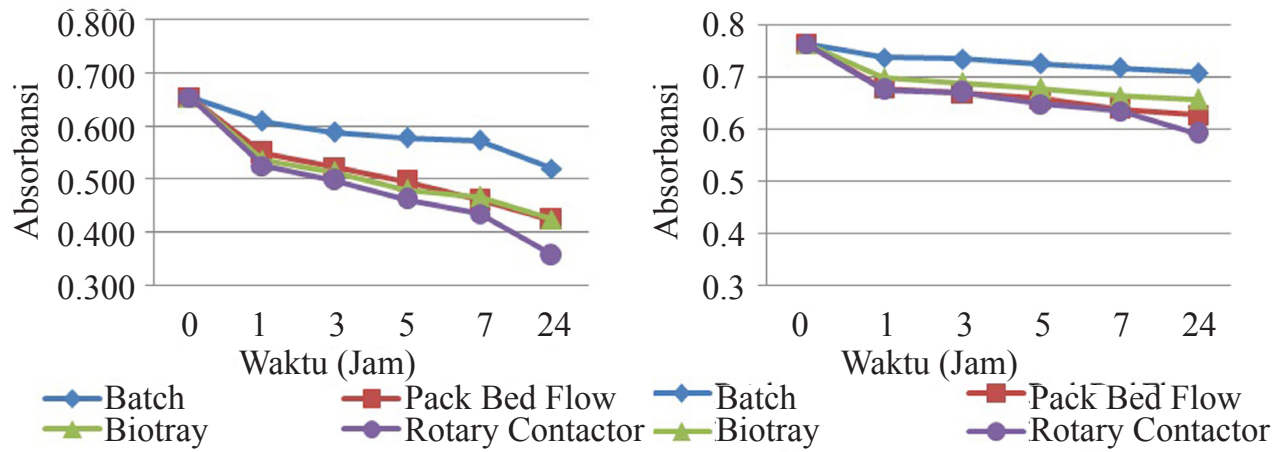

Gambar 2 Penurunan absorbansi warna merah lombok pada (a) konsentrasi 50 ppm; (b) konsentrasi 150 ppm 
menjadi 0.709, pada metode pack bed flow menjadi 0.629, pada metode biotray menjadi 0.658 , pada metode rotary contactor menjadi 0.592 (Gambar 2b).

\section{Persentase Penyerapan Zat Warna Merah Lombok}

Persentase penyerapan zat warna merah lombok dihitung untuk melihat kemampuan jamur Omphalina sp dalam menurunkan nilai absorban zat warna merah lombok yang diukur dari penurunan nilai absorban pada jam ke-1, 3, 5, 7, dan 24 terhadap kontrol. Persentase penyerapan pada konsentrasi awal 50 ppm, pada jam ke-24 pada metode batch, pack bed flow, biotray dan rotary contactor secara berurutan adalah $20.550 \%, 35.447 \%, 35.141 \%$ dan $45.531 \%$ (Gambar 3a). Konsentrasi awal 150 ppm menghasilkan persentase penyerapan pada jam ke-24 pada metode batch adalah $7.320 \%$, pada metode pack bed flow adalah $17.843 \%$, pada metode biotray adalah $13.987 \%$ dan pada metode rotary contactor adalah $22.614 \%$ (Gambar 3b).

\section{Serapan Maksimum $\left(q_{\text {maks }}\right)$ Zat Warna Merah Lombok}

Serapan maksimum zat warna dihitung dengan membandingkan antara serapan warna dalam biosorben (mg zat warna/g biosorben)

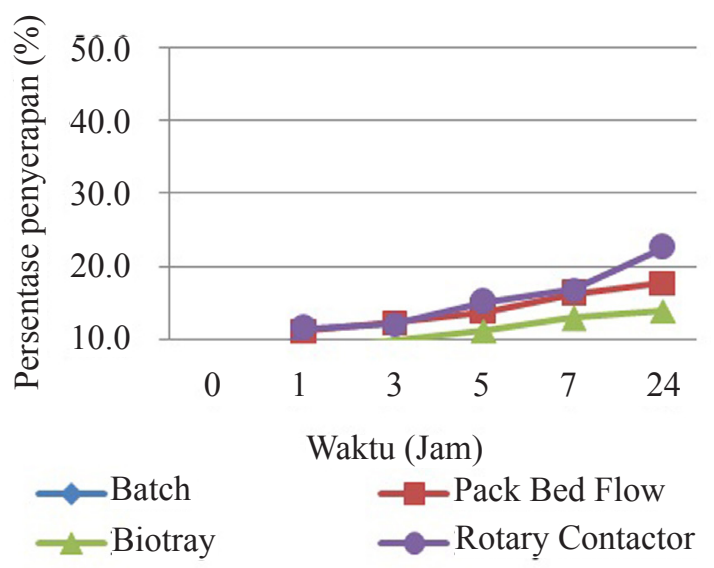

Gambar 3 Persentase penyerapan zat warna merah lombok pada (a) konsentrasi 50 ppm; (b) konsentrasi $150 \mathrm{ppm}$.

Tabel 1 Hasil penentuan nilai $\mathrm{q}_{\text {maks }}$

\begin{tabular}{lcccc}
\hline \multicolumn{1}{c}{ Metode } & $\mathrm{R}^{2}$ & Persamaan & qmax & $\mathrm{b}$ \\
\hline Merah lombok 50 ppm & & & 0.020 & 0.027 \\
Bacth & 0.824 & $-1815 . \mathrm{x}+48.85$ & 0.076 & 0.036 \\
Pack Bed Flow & 0.907 & $-362.3 \mathrm{x}+13.20$ & 0.083 & 0.037 \\
Biotry & 0.926 & $-321.7 \mathrm{x}+11.98$ & 0.124 & 0.045 \\
Rotary Contactor & 0.863 & $-177.7 \mathrm{x}+8.052$ & & 0.007 \\
Merah lombok 150 ppm & & & 0.009 & 0.009 \\
Bacth & 0.95 & $-14211 \mathrm{x}+105.5$ & 0.077 & 0.008 \\
Pack Bed Flow & 0.979 & $-1427 . \mathrm{x}+13.03$ & 0.046 & 0.010 \\
Biotry & 0.978 & $-2539 . \mathrm{x}+21.53$ & 0.100 & \\
Rotary Contactor & 0.942 & $-1030 . \mathrm{x}+9.969$ & & \\
\hline
\end{tabular}


dengan konsentrasi akhir (keseimbangan) zat warna dalam larutan yang dibuat dalam plot grafik, sehingga didapatkan $\mathrm{q}_{\text {maks }}$ pada masingmasing metode. Serapan maksimal $\left(\mathrm{q}_{\text {maks }}\right)$ yang ditunjukkan pada Tabel 1 yaitu pada metode rotary contactor bernilai 0.124 pada konsentrasi 50 ppm dan 0.100 pada konsentrasi 150 ppm. Semakin besar nilai $\mathrm{q}_{\text {maks }}$ menunjukkan semakin besar serapan jamur pelapuk putih dalam melakukan proses dekolorisasi. Serapan paling rendah ditunjukkan oleh metode batch dengan nilai $\mathrm{q}_{\text {maks }}$ paling kecil, yaitu 0.020 pada konsentrasi 50 ppm dan 0.009 pada konsentrasi 150 ppm.

\section{Kemampuan Deodorisasi}

Penurunan bau pada ke empat metode ditentukan melalui penurunan skala bau. Skala bau pada jam ke-24 dengan metode batch adalah 2.9, dengan metode pack bed flow sebesar 1.4, dengan metode biotray sebesar 1.6, dan dengan metode rotary contactor sebesar 1.1. Hal ini menunjukkan bahwa penurunan skala bau paling besar terjadi pada metode rotary contactor, sedangkan penurunan skala paling kecil terjadi pada metode batch (Gambar 4).

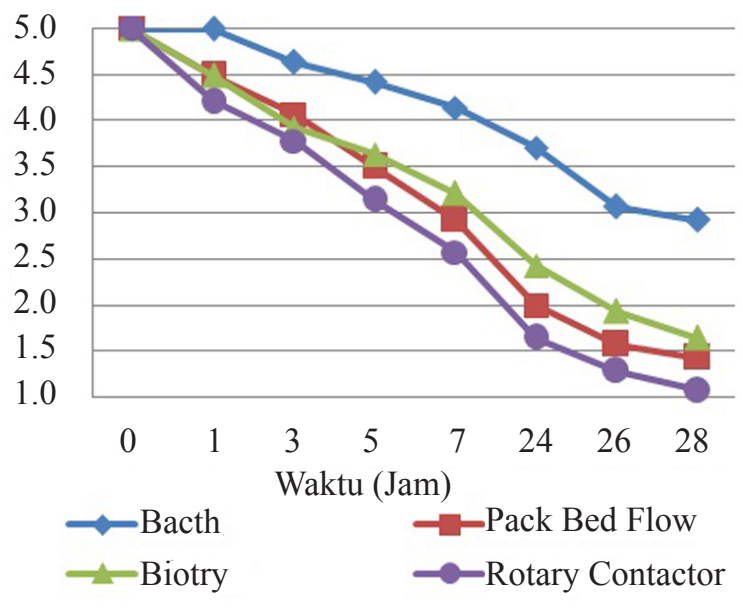

Gambar 6 Penurunan skala bau

\section{PEMBAHASAN}

Penurunan absorbansi ini menunjukkan telah terjadinya proses dekolorisasi pada masing-masing metode dengan tingkat penurunan yang berbeda-beda. Yaropolov et al. (1994) menyatakan bahwa enzim ekstraseluler pada jamur pelapuk putih (lakase) dapat mengoksidasi ika$\tan$ azo $(-\mathrm{N}=\mathrm{N}-)$ yang merupakan gugus kromofor menjadi gugus $-\mathrm{OH}$ dan $\mathrm{N}_{2}$. Gugus kromofor ini mengakibatkan munculnya warna melalui pengubahan spektrum serapan pada daerah tampak (visible). Gugus kromofor diantaranya gugus etilen $(-\mathrm{C}=\mathrm{C}-)$, gugus karbon nitrogen $(-\mathrm{C}=\mathrm{NH}-$ , $-\mathrm{CH}=\mathrm{N}-)$, gugus karbonil $(-\mathrm{C}=\mathrm{O})$, gugus azo $(-\mathrm{N}=\mathrm{N}-)$, gugus nitro (-NO2), dan gugus nitroso (-NO) (Van der Zee 2002).

Persentase penyerapan pada masingmasing metode berbeda-beda, semakin tinggi konsentrasi zat warna yang didegradasi maka akan semakin kecil nilai penurunan absorbansi zat warna tersebut. Persentase penyerapan pada metode kontinyu secara keseluruhan lebih besar dari pada persentase penyerapan pada metode batch, karena pada metode kontinyu zat warna dialirkan secara kontinyu menuju Omphalina sp, sehingga intensitas zat warna mengalami penurunan lebih besar dibandingkan pada metode batch dimana pada metode batch hanya bagian atas dari larutan zat warna yang mengalami kontak dengan omphalina sp.

Jamur pelapuk putih Omphalina sp memiliki kemampuan untuk menurunkan bau pada limbah, sehingga perlu dilakukan pengujian jenis limbah berbau yang dapat diolah menggunakan jamur pelapuk putih Omphalina sp. Ada 26 jenis senyawa yang menjadi sumber bau dari hasil kegiatan industri. Tiga dari 26 jenis senyawa tersebut dijadikan parameter acuan kebauan 
dalam Kepmen No.50/MenLH/II/1996 yaitu metil merkaptan $\left(\mathrm{CH}_{3} \mathrm{SH}\right)$, amoniak $\left(\mathrm{NH}_{3}\right)$, dan hidrogen sulfida $\left(\mathrm{H}_{2} \mathrm{~S}\right)$. Kebauan merupakan bau yang tidak diinginkan pada kadar dan waktu tertentu yang mengganggu kesehatan manusia dan kenyamanan lingkungan (Kepmen No.50/ MenLH/II/1996 dalam Kosasih 2003). Bau yang tercium pada limbah lateks ini adalah bau amoniak $\left(\mathrm{NH}_{3}\right)$. Bau ini muncul karena terjadinya biodegradasi protein menjadi asam amino yang mengeluarkan $\mathrm{NH}_{3}$ melalui jalur metabolisme. Penurunan bau yang terjadi selama proses deodorisasi menunjukkan telah terjadinya penguraian zat-zat organik oleh Omphalina sp (Azizah 2008). Enzim lakase yang terdapat pada Omphalina sp mampu mengkatalisis penguraian berbagai substrat (Thurston 1994).

Deodorisasi dan dekolorisasi pada limbah dapat dilakukan dengan menggunakan jamur pelapuk putih. Deodorisasi limbah lateks dan dekolorisasi zat pewarna tekstil dengan jamur pelapuk putih Omphalina sp menggunakan metode batch dan kontinyu berhasil dilakukan. Deodorisasi limbah lateks paling baik dilakukan dengan menggunakan metode rotary contactor. Dekolorisasi limbah tekstil paling baik dilakukan dengan menggunakan metode rotary contactor, berdasarkan penurunan nilai absorbansi, kenaikan persen penyerapan zat warna, dan nilai serapan maksimal $\left(\mathrm{q}_{\text {maks }}\right)$

\section{UCAPAN TERIMA KASIH}

Penulis mengucapkan terimakasih kepada Pusat Penelitian Bioteknologi dan Bioindustri Indonesia yang berkenan memberikan kesempatan kepada penulis untuk melakukan penelitian di Laboratorium Mikroba dan Bioproses.

\section{DAFTAR PUSTAKA}

Ardhina, A. 2007. Dekolorisasi limbah cair industri tekstil menggunakan Omphalina sp [Skripsi]. Bogor. Institut Pertanian Bogor.

Awaluddin R, et al. 2001. Decolorization of commercially available synthetic dyes by the white rot fungus Phanerochaete chrysosporium. J Fungi and Bactery. 62:55-63.

Azizah RN 2008. Deodorisasi Limbah Lateks Pekat dan Dekolorisasi Zat Pewarna Tekstil Secara Enzimatis dengan Formula Omphalina sp [Sripsi]. Bogor. Institut Pertanian Bogor.

Bakshi RK, Gupta KG, Sharma P. 1999. Enhanced biodecolourisation of synthetic textile dye effluent by Phanerochaete chrysosporium under improved culture conditions. World $J$ Microbiol Biotechnol. 15:507-509.

Buckley KF, Dobson DW. 1998. Extracellular ligninolytic enzyme production and polymeric dye decolourisation in immobilized cultures of Chrysosporium lignorum CL 1. Biotechnol Lett 20:301-306.

Budiawan. 2001. Pengkajian Keputusan Menteri Lingkungan Hidup No.50/MenLH/II/1996 Tentang Resiko dan Keselamatan Lingkungan. [Laporan penelitian]. Depok: Fakultas Matematika dan Ilmu Pengetahuan Alam, Universitas Indonesia. Jakarta.

Dimawarnita F, et al. 2015. Biosorpsi ion tembaga dalam limbah tailing menggunakan jamur pelapuk putih amobil. Menara Perkebunan. 83(1): 27-36.

Gill PK, Arora DS, Chander M. 2002. Biodecolourisation of azo and triphenylmethane dyes by Dichomitus squalens and Phlebia spp. J Ind Microbiol Biotechnol 28:201-203.

Kosasih H. 2003. Studi deodorisasi pada lateks secara mikrobiologi menggunakan isolat bakteri. Skripsi (tidak dipublikasikan). Fakultas Matematika dan Ilmu Pengetahuan Alam, Universitas Indonesia. Jakarta. 
Robinson T, Chandran B, Nigam P. 2001. Studies on the decolourisation of an artificial textile effluent by white-rot fungi in N-rich and Nlimited media. Appl Microbiol Biotechnol. $57: 810-813$.

Stolz A. 2001. Basic and applied aspects in the microbialdegradation of azo dyes. Appl Microbiol Biotechnol 56:69-80.

Thurston CF. 1994. The structure and function of fungal laccase. Microbiology. 140: 19-26.

Van der Zee. 2002. Anaerobic azo dye reduction [Thesis]. Wageningen University. Nedherlands.

Wesenberg D, Buchon F, Agathos SN. 2002. Degradation of dye containing textile effluent by agaric white-rot fungi Clitocybula dusenii. Biotechnol Lett 24:989-993. 